\title{
Sexual dimorphism in Liolaemus occipitalis (Iguania, Tropiduridae) ${ }^{1}$
}

\author{
Laura Verrastro ${ }^{2}$
}

1. Contribuição no 404, Depto de Zoologia, Universidade Federal do Rio Grande do Sul (UFRGS).
2. Depto de Zoologia, UFRGS, Av. Bento Gonçalves, 9500, 91501-970, Porto Alegre, RS, Brasil. (lauraver@vortex.ufrgs.br)

\begin{abstract}
The sexual dimorphism in size, morphology and color of the lizard Liolaemus occipitalis Boulenger, 1885 was studied. Thirty-two adult males and twenty-eight adult females were sampled from a population in the Jardim do Éden beach, near Tramandaí, Rio Grande do Sul, Brazil. Size related sexual dimorphism occurred in all compared body dimensions. The largest female was $59.6 \mathrm{~mm}$ in snout-vent length, and the largest male was $69.3 \mathrm{~mm}$. Males and females also presented differences in ventral and dorsal color pattern, and in the presence of pre-cloacal pores. The results suggest that, in Liolaemus occipitalis, sexual dimorphism in size is determined by sexual selection, competition between males and by the high energetic cost for females a few months after hatching.
\end{abstract}

KEYWORDS. Sauria, Liolaemus, sexual dimorphism, sexual selection.

\section{INTRODUCTION}

Sexual dimorphism can be observed in morphology, color pattern and behavior. Some authors discuss the evolution of size related sexual dimorphism in birds (Selander, 1972), primates (CROOK, 1972), amphibians (Woolbright, 1983), insectivorous lizards (STAMPS, 1983), omnivorous lizards (Rocha, 1996) and herbivorous lizards (CAROTHERS, 1984).

According to CAROTHERS (1984), sexual dimorphism is determined by three factors: female reproductive strategy (Tinkle et al., 1970), sexual selection (CAROTHERS, 1984) and competition for food resources (SCHOENER, 1967). ANDERSON \& VitT (1990) suggest that the causes of sexual dimorphism in size could be related to several factors: competition between males; differential mortality between sexes due to differences in longevity; larger amount of energy allocated by females for reproduction; males are more active because they need to search for females and thus present a larger predation risk. These authors also suggest that sexual dimorphism could be connected to the feeding strategy which is directly related to phylogenetic characteristics of the family.

Other studies dealing specifically with lizards have demonstrated that a size difference between sexes determines segregation in food resource utilization (RAND, 1967; Selander, 1972; Roughgarden, 1974; SCHOENER, 1977; StAMPs, 1977b). Both body size and relative size of the head have been mentioned as factors that facilitate food partitioning (SCHOENER, 1967; 1977). Sexual selection also acts on competition between males, often resulting in larger body size and in larger sizes of morphological structures related to fight (DARWIN, 1874). The males of territorial iguanids (STAMPS, 1977b) are usually larger than females (FITCH, 1980), what suggests the existence of a relation between sexual selection and sexual dimorphism (TRIVERS, 1976; StAMPS, 1983). Thus, when a larger body size is favored in male choice by females, selection tends to promote an increase in male size relative to female size (VITT \& COOPER, 1985).
The genus Liolaemus Wiegmann, 1883, is represented by two species in Rio Grande do Sul: $L$. occipitalis Boulenger, 1885, and L. arambarensis Verrastro, 2003 (VERRASTRO et al., 2003). The distribution of $L$. occipitalis is restricted to the coastal sand dunes of Rio Grande do Sul and Santa Catarina (Müller \& Steiniger, 1977). It is a carnivorous, basically insectivorous lizard, which reproduces between September and March (Verrastro \& Krause, 1999). VerRastro \& Krause (1994) observed that this species attains sexual maturity in the first reproductive season after they were born. Differences in growth rates, between juvenile males and females, and in adult size were also observed.

The objective is to describe sexual dimorphism in Liolaemus occipitalis.

\section{MATERIAL AND METHODS}

Specimens were captured in Jardim do Éden beach $\left(30^{\circ} 05^{\prime} \mathrm{S}, 50^{\circ} 10^{\prime} \mathrm{W}\right)$, situated $10 \mathrm{~km}$ from Tramandaí, next to the RST 786 road linking Cidreira to Tramandaí, RS. The sampling area is about $1000 \mathrm{~m}$ from the ocean and 500 m east from lake Gentil. The region is typically characterized by moving sand dunes, and covered by sparse vegetation (Gramineae).

Manual collection of female and male specimens was done in 1996. A total of 28 adult males and 31 adult females was selected for obtaining biometric data. Specimen selection was based in Verrastro \& Krause (1994; 1999), which describe the minimum size of an adult male as $50.0 \mathrm{~mm}$ and of adult female as $45.5 \mathrm{~mm}$, and the size relations and morphological characteristics of individuals hatched in the same reproductive season. According to the later authors, the growth rates after sexual maturity decrease considerably, reaching values close to zero when individuals are larger than the mean adult size. Adult individuals larger than the mean adult size were selected in order to avoid the influence of age in the sample. Biometric variables used in the analysis were snout-vent length (SVL), head width (HW), head 
length (HL), tale base length (TBL) and lower jaw length (LJL). Means were calculated after three measurements for each variable. Statistical comparisons were made using the Mann-Whitney test. Additionally, the presence of cloacal pores was also analyzed and the dorsal and ventral color pattern was compared between males and females, in a total of 128 individuals: 73 adults (42 males and 31 females) and 55 young ( 28 males and 27 females). The color pattern was registered in the field, before fixation of the individuals.

All analyzed specimens are catalogued in the collection of the Laboratório de Herpetologia, Universidade Federal do Rio Grande do Sul (UFRS).

\section{RESULTS}

The data obtained indicated a marked sexual dimorphism in Liolaemus occipitalis, both in size and morphology.

Adult males tend to be larger than females with significant differences being found in the five biometric measurements tested (tab. I).

The largest snout-vent length observed in females was $59.6 \mathrm{~mm}$, and $69.3 \mathrm{~mm}$ in males. The mean value for adult females was $53.5 \mathrm{~mm}$, and for adult males, $60.4 \mathrm{~mm}$. Maximum size and mean size of males were $16.3 \%$ and $12.9 \%$ larger than females, respectively. In addition to the biometric differences, morphological contrasts between males and females were also found. In females (fig. 1), the margin of the cloaca forms a sharp angle (Vshaped) and pre-cloacal pores are absent. In males, the margin of the cloaca is less angular (U-shaped) and presents 4 to 8 orange cloacal pores (fig. 1).
Table I. Biometric data $(\mathrm{mm})$ for adult females and males of Liolaemus occipitalis (SVL, snout-vent length; HL, head length; HW, head width; TBL, tale base length; LJL, lower jaw length; SD, standard deviation; n, number of specimens; *, indicates significantly different proportions $(\mathrm{p}<0.0001)$, Mann-Whitney test).

\begin{tabular}{|c|c|c|c|c|c|c|c|}
\hline \multirow[b]{2}{*}{ Variable } & \multicolumn{3}{|c|}{ Females $(\mathrm{n}=32)$} & \multicolumn{3}{|c|}{ Males $(\mathrm{n}=28)$} & \multirow[b]{2}{*}{ test } \\
\hline & Min & mean $\pm \mathrm{SD}$ & $\operatorname{Max}$ & Min & mean $\pm \mathrm{SD}$ & Max & \\
\hline SVL & 46.3 & $53.18 \pm$ & 59.6 & 50.3 & $60.41 \pm$ & 69.3 & $*$ \\
\hline $\mathrm{HL}$ & 10.0 & $11.51 \pm 0.689$ & 12.9 & 11.5 & $13.23 \pm 0.984$ & 14.8 & $*$ \\
\hline HW & 7.3 & $8.92 \pm 0.623$ & 10.2 & 9.3 & $10.63 \pm 0.854$ & 12.2 & $*$ \\
\hline TBL & 5.7 & $6.26 \pm 0.418$ & 7.2 & 6.5 & $8.10 \pm 0.788$ & 9.5 & $*$ \\
\hline LJL & 9.7 & $10.85 \pm 0.590$ & 11.8 & 10.5 & $12.48 \pm 0.965$ & 14.5 & $*$ \\
\hline
\end{tabular}

Males and females also differed in color pattern. Adult males present a black stripe in the dorso-lateral region of the body and black spots in the gular region (tab. II). Females usually present a pale dorsal color. The gular region of both adult and young females can be either completely covered, filled, or spotted by an intense

Table II. Color pattern and pre-cloacal pores in Liolaemus occipitalis ( $\mathrm{P}$, present; $\mathrm{A}$, absent; $\mathrm{O}$, occasionally).

\begin{tabular}{lcccc}
\hline sex/age & black strip & black spots & yellow spots & pores \\
\hline adult male & $\mathrm{P}$ & $\mathrm{P}$ & $\mathrm{A}$ & $\mathrm{P}$ \\
adult female $\left(2^{\text {nd }}\right.$ year $)$ & $\mathrm{P} / \mathrm{O}$ & $\mathrm{P} / \mathrm{O}$ & $\mathrm{A}$ & $\mathrm{A}$ \\
adult female $\left(1^{\text {st }}\right.$ year $)$ & $\mathrm{A}$ & $\mathrm{A}$ & $\mathrm{P} / \mathrm{O}$ & $\mathrm{A}$ \\
young male & $\mathrm{A}$ & $\mathrm{A}$ & $\mathrm{A}$ & $\mathrm{P}$ \\
young female & $\mathrm{A}$ & $\mathrm{A}$ & $\mathrm{P}$ & $\mathrm{A}$ \\
\hline
\end{tabular}

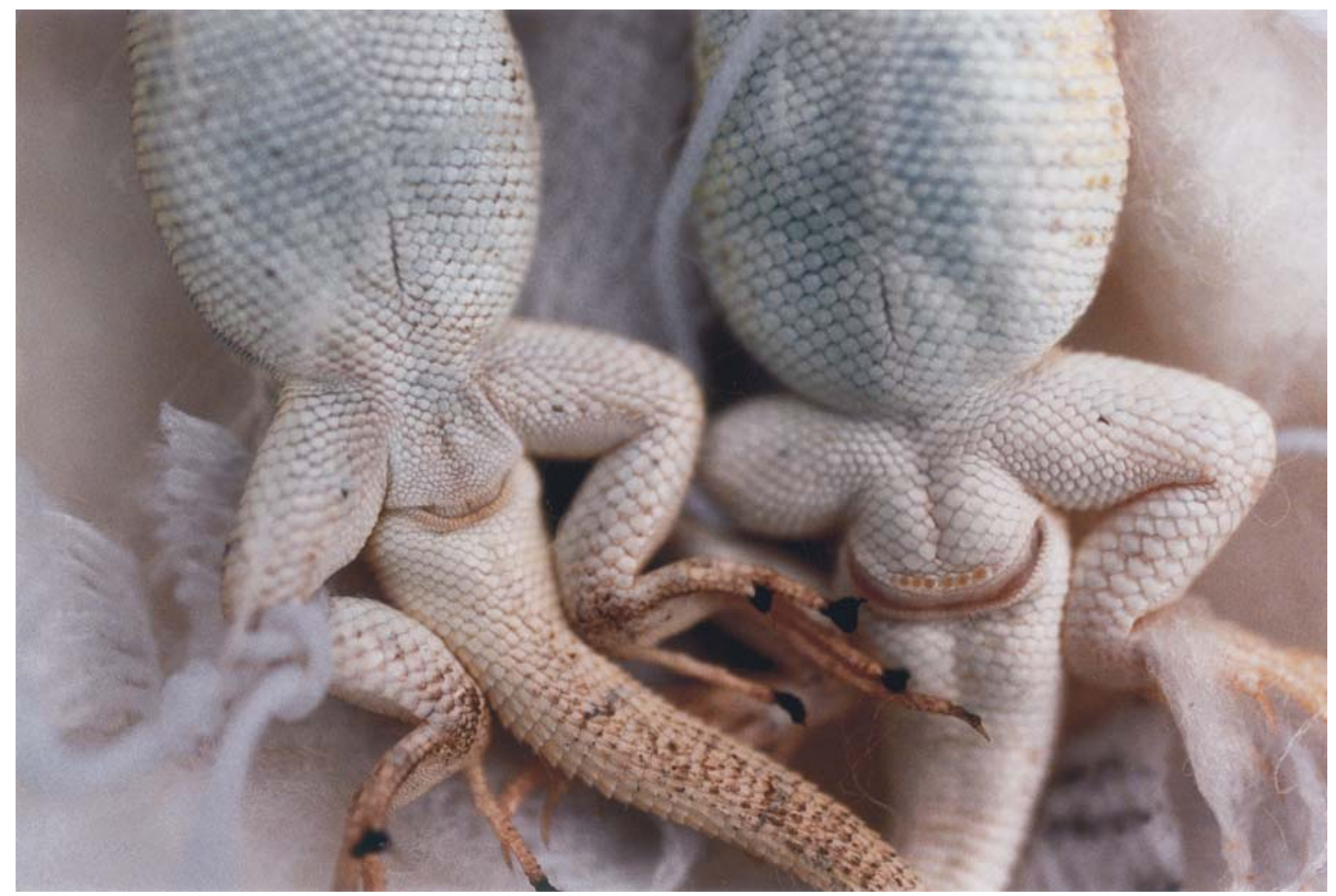

Fig. 1. Morphological sexual dimorphism in Liolaemus occipitalis: form of the cloaca and the pre-cloacal pores in the male (right specimen, UFRS 2865, SVL=61,2 mm); female (left, UFRS 2853, $\mathrm{SVL}=54,9 \mathrm{~mm}$ ). 
yellowish color, which is more evident soon after hatching or during the breeding season (fig. 2). During the second year of life, some females may also present the black spots or the black strip in the dorso-lateral region.

Agonistic encounters between males were observed in the field. As a result of these encounters, males presented injuries in the head and neck, which were most evident in the breeding season. Building of lurking

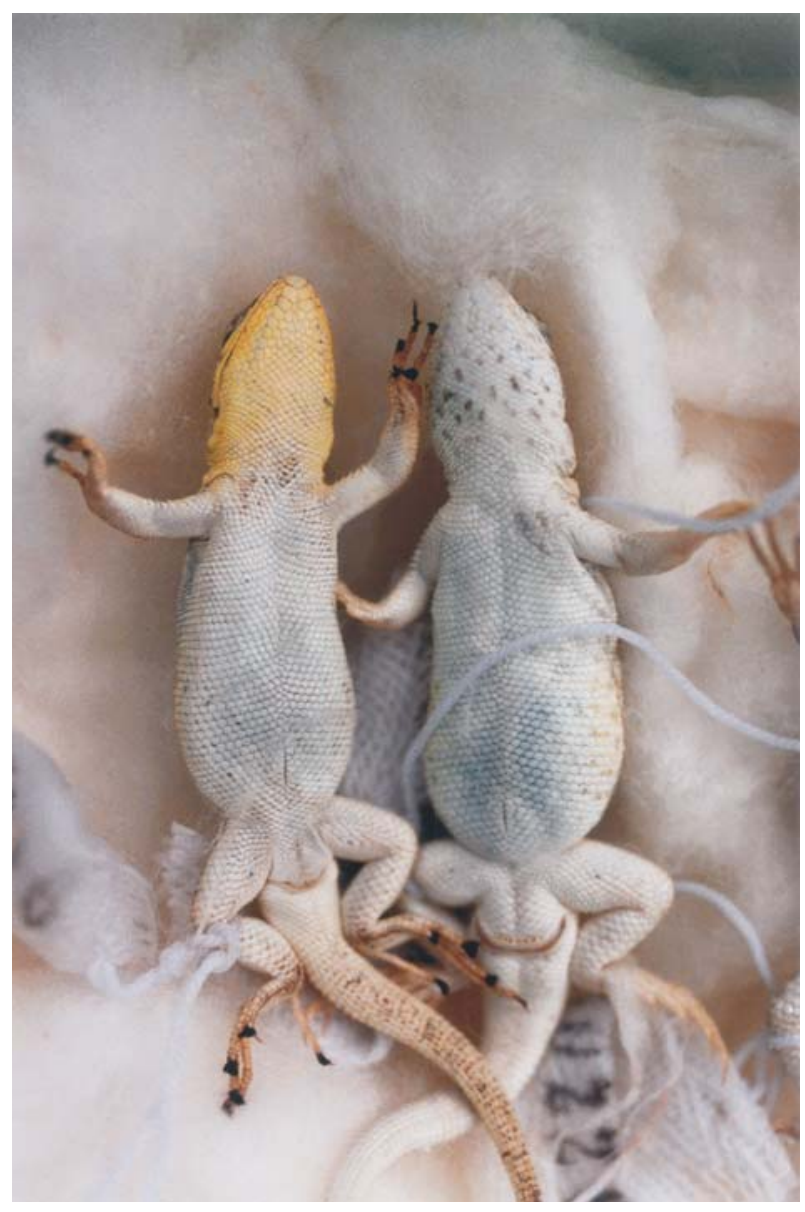

Fig. 2. Morphological and ventral color sexual dimorphism in Liolaemus occipitalis: female (left specimen, UFRS 2853, $\mathrm{SVL}=54,9 \mathrm{~mm}$ ), gular region, yellow; male (right, UFRS 2865, $\mathrm{SVL}=61,2 \mathrm{~mm}$ ), gular region with black spots and cloacal pores.

holes was also observed during the reproductive season (September to March), when mainly adult males occupied holes. There was no record of two males occupying the same hole, except for one case where the second male was a dead young individual showing evident injuries.

\section{DISCUSSION}

Liolaemus occipitalis presented marked sexual dimorphism in size, with males significantly larger than females in all measured body dimensions. Some authors have observed that, in females, energy allocation to reproduction results in smaller body and smaller relative head size (COOPER \& VitT, 1989; Rocha, 1996). According to Verrastro \& Krause (1999), L. occipitalis reaches sexual maturity during the first year of life, in the first reproductive season after hatching. This situation implies females allocate a lot of energy to reproduction for producing their first clutch. Females have their growth rates reduced before males, growing at lower rates in winter and spring (VerRastro \& KRAUSE, 1994).

According to CAROTHERS (1984), sexual dimorphism can be the result of sexual selection as a mechanism for reducing competition for food between males and females. Numerous studies on insectivorous lizards have shown that size differences between sexes are related to segregation of food resources (RAND, 1967; SElander, 1972; SChOENER, 1977; STAMPs, 1977a). Both body size and relative size of the head have been mentioned as factors that facilitate food resource partitioning (Schoener, 1967; 1977). Rocha (1996) related sexual dimorphism in size of Liolaemus lutzae Mertens, 1938 to sexual selection, which is associated to its omnivorous diet in early life stages and to herbivorous diet in adult individuals, as well as to territorial behavior. The later author followed CAROTHERS (1984), which considers sexual selection as the most important factor influencing sexual dimorphism in size of herbivorous lizards. If diet differences between sexes occur in L. occipitalis (an insectivorous lizard), it is possible that competition for food between males and females could be one of the factors determining sexual dimorphism. According to the present knowledge about the diet of this species it can be suggested that differences in consumption of food items do no support competition as a main factor in the determination of sexual dimorphism. Home range data indicate this species presents territorial behavior, with larger males being more successful in determining territories and in choosing females. For males, larger sizes usually imply an increase in competitive ability. Therefore, in situations where a larger size is favored in the choice of males by females, selection tends to promote an increase in male size relative to females (VITT \& COOPER, 1985). Sexual selection often causes males to present larger body and mandible sizes, which are characteristics linked to success in fighting (CARPENTER \& FERGUNSON, 1977; Carothers, 1984). This was observed in $L$. occipitalis, as males presented mandibles significantly larger than females. Males of territorial iguanid species are usually larger than females (STAMPS, 1977b; Fiтch, 1980), what suggests a relation between sexual selection and dimorphism (TRIVERS, 1976; STAMPS, 1983). Therefore, the sexual selection due to competition between males, and the high energetic allocation of females a few months after hatching, could be selective forces with preponderant action on the determination of sexual dimorphism of body size in L. occipitalis.

Females and males also differed in the dorsal and ventral color pattern, with males presenting a darker dorsal color than females. Differences in the color pattern of females and males were observed in several Liolaemus species, with males generally being more colorful (Etheridge, 2000). In L. lutzae Mertens, 1938, RochA (1996) observed orange colors in the ventral side of the thighs. Males of L. multimaculatus Boulenger, 1885, L. rabinoi Cei, 1974, and L. salinicola Laurent, 1986 present black blotches in the throat (ETHERIDGE, 2000). These color differences are quite probably associated to intra- and intersexual recognition. 
Another difference between females and males is that only the later present cloacal pores. These pores were always more colorful and opened during the reproductive season. Similarly to L. occipitalis, females of other Liolaemus species also lack cloacal pores, e.g. L. lutzae, L. multimaculatus, L. rabinoi, L. riojanus Cei, 1979, L. salinicola Laurent, 1986 (CEI, 1974, 1979; LAURENT, 1986; Rocha, 1996). In those species in which cloacal pores were observed in both sexes, females presented always a smaller number of pores than males $(L$. scapularis Laurent, 1982; L. wiegmannii Dumeril \& Bibron, 1837) (LAurent, 1982; RamireZ-Pinilla, 1991). Cloacal pores are tegumentary glands that would be responsible for producing secretions to stimulate copulation (Pope, 1956 apud RocHA, 1996).

Acknowledgments. To my colleagues Dr. L. Krause, Dr. C. Keller, Dr. J. Zocche and Dr. P. Brack for helping in field work. To Dr. L. R. Malabarba (UFRGS) for critically reviewing the manuscript. To CAPES, for conceding a grant.

\section{REFERENCES}

Anderson, R. A. \& VitT, L. J. 1990. Sexual selection versus alternative causes of sexual dimorphism in teiid lizards. Oecologia, Heidelberg, 84:145-157.

Carothers, J. H. 1984. Sexual selection and sexual dimorphism in some herbivorous lizards. American Naturalist, Chicago, 124:244-254.

Carpenter, C. C. \& Fergunson, G. W. 1977. Variation and evolution of stereotyped behavior in reptiles. In: GaNs, C. \& Tinkle, D. W. eds. Biology of the Reptilia. London, Academic. v. 7A, p.335-554.

Cei, J. M. 1974. Two new species of Ctenoblepharis (Reptilia, Iguanidae) from the arid environments of the central Argentina (Mendoza Province). Journal of Herpetology, Claremont, 8(1):71-75.

1979. A reassessment of the genus Ctenoblepharis (Reptilia, Sauria, Iguanidae) with a description of new subspecies of Liolaemus multimaculatus from western Argentina. Journal of Herpetology, Claremont, 13(3):297-302.

Cooper, W. E., JR. \& VitT, L. J. 1989. Sexual dimorphism of head and body size in an iguanid lizard: paradoxical results. American Naturalist, Chicago, 133:729-735.

CROOK, J. H. 1972. Sexual selection, dimorphism, and social organization in the primates. In: CAmpbell, R. ed. Sexual selection and the descent of man. Chicago, Aldine. p. 231-281.

Darwin, C. R. 1874. The descent of man, and selection in relation to sex. 2. ed. London, J. Murray. 352p.

ETHERIDGe, R. 2000. A review of lizards of the Liolaemus wiegmannii group (Squamata, Iguania, Tropiduridae), and a history of morphological change in the sand-dwelling species. Herpetological Monographs, Emporia, 14:293352 .

Fitch, H. S. 1980. Reproductive strategies of reptiles. SSAR Contributions to Herpetology 1. In: Murphy, J. B. \& Collins, J. J. eds. Reproductive biology and diseases of captive reptiles. New York, Society for the Study of Amphibians and Reptiles. p. 25-31.
Laurent, R. F. 1982. Description de trois espèces nouvelles du genre Liolaemus (Sauria, Iguanidae). Spixiana, München, 5(2):139-147.

_. 1986. Descripciones de nuevos Iguanidae del genero Liolaemus. Acta Zoologica Lilloana, Tucumán, 38(2):87-105.

Müller, P. \& Steiniger, H. 1977. Evolutionsgeschwindiakeit, verbreitung und verwandtschaft Brasilianisher Erdleguane der Gattung Liolaemus (Sauria-Iguanidae). Mitteilungen Schwerpunkt für Biogeographie der Universität des Saarlandes, Saarbrüken, 9:1-17.

RamiREz-Pinilla, M. P. 1991. Reproductive and fat body cycles of the lizard Liolaemus wiegmanni. Amphibia Reptilia, Leiden, 12(2):195-202.

RAND, A. S. 1967. Ecology and social organization of Anolis lineatopus, Proceedings of the United States National Museum, Washington, 122:1-79.

Rocha, C. F. D. 1996. Sexual dimorphism in the sand lizard Liolaemus lutzae of southeastern Brazil. In: PÉFAUR J. E. ed. Herpetologia Neotropical. Mérida, Universidad de los Andes, Conselho de Publicaciones, v. 2, p.131-140.

Roughgarden, J. 1974. Niche width: biogeographic patterns among Anolis lizard populations. American Naturalist, Chicago, 108:429-442.

Schoener, T. W. 1967. The ecological significance of sexual dimorphism in size in the lizard Anolis conspersus. Science, Stanford, 155:474-477.

1977. Competition and the niche. In: Gans, C. \& Tinkle, D. W. eds. Biology of the Reptilia. London, Academic. v.7A, p. $35-136$.

Selander, R. K. 1972. Sexual selection and dimorphism in bird. In: Campbell, B. ed. Sexual selection and the descent of man. Chicago, Aldine. p.180-230.

StAmps, J. A. 1977a. Social behavior and spacing patterns in lizards. In: Gans, C. \& Tinkle, D. W. eds. Biology of the Reptilia, London, Academic. v.7A, p.265-335.

1977b. The relationship between resource competition risk, and aggression in a tropical lizard. Ecology, Tempe, 58:349-358.

1983. Sexual selection, sexual dimorphism and territoriality in lizards. In: Huey, R. B.; Pianka, E. R. \& Schoener, T. W. eds. Lizard ecology: studies on a model organism. Cambridge, Harvard University. p.169-204.

Tinkle, D. W.; Wilbur, H. M. \& Tilley, S. G. 1970. Evolutionary strategies in lizard reproduction. Evolution, Lawrence, 24:55-74.

Trivers, R. L. 1976. Sexual selection and resource-accruing abilities in Anolis garmani. Evolution, Lawrence, 30:253-269.

Verrastro, L. \& Krause, L. 1994. Analysis of growth in a population of Liolaemus occipitalis Boul. 1885, from the coastal sand-dunes of Tramandaí, RS, Brazil (ReptiliaIguanidae). Studies on Neotropical Fauna and Environment, Sassenheim, 29(2):99-111.

1999. Ciclo reprodutivo de machos de Liolaemus occipitalis Boulenger (Sauria, Tropiduridae). Revista Brasileira de Zoologia, Curitiba, 16(1):227-231.

Verrastro, L.; Veronese, L. et al. 2003. A new species of Liolaemus from southern Brazil (Iguania, Tropiduridae). Herpetology, Emporia, 59(1):252-277.

VITT, L. J. \& CoOper, W. E., JR. 1985. The evolution of sexual dimorphism in the skink Eumaces laticeps: an example of sexual selection. Canadian Journal of Zoology, Ottawa, 63:995-1002.

Woolbright, L. L. 1983. Sexual selection and size dimorphism in anuran Amphibia. American Naturalist, Chicago, 121:110-119. 